THE PSYCHOLOGY OF BEHAVIOUR IN ORGANIZATIONS 
Also by Elizabeth Chell

PARTICIPATION AND ORGANIZATION:

A Social Psychological Approach

THE ENTREPRENEURIAL PERSONALITY:

Concepts, Cares and Categories

(with J. M. Haworth and S. A. Brearley) 


\title{
THE PSYCHOLOGY OF BEHAVIOUR IN ORGANIZATIONS
}

\author{
Second Edition
}

\author{
Elizabeth Chell \\ Alcan Professor of Management, School of Business Management \\ University of Newcastle upon Tyne
}


All rights reserved. No reproduction, copy or transmission of this publication may be made without written permission.

No paragraph of this publication may be reproduced, copied or transmitted save with written permission or in accordance with the provisions of the Copyright, Designs and Patents Act 1988, or under the terms of any licence permitting limited copying issued by the Copyright Licensing Agency, 90 Tottenham Court Road, London W1P 9HE.

Any person who does any unauthorised act in relation to this publication may be liable to criminal prosecution and civil claims for damages.

First published 1987 by

THE MACMILLAN PRESS LTD

Houndmills, Basingstoke, Hampshire RG21 2XS

and London

Companies and representatives

throughout the world

ISBN 978-0-333-57001-2

ISBN 978-1-349-22939-0 (eBook)

DOI 10.1007/978-1-349-22939-0

A catalogue record for this book is available

from the British Library.

First edition reprinted 1989, 1990 (twice), 1991

Second edition 1993

Reprinted 1994 


\section{Contents}

Tables

Figures

Preface to the Second Edition

viii

ix

$\mathrm{X}$

1 What Types of People?

The Nature of Personality

Disillusionment with the Trait Concept of Personality

The Influence of Situations in Determining Behaviour: Interactionism

The Application of Interactionism to an Understanding of Work-related Behaviour

The Roles People Play: An Analysis of the Situation-Act Model

The Construction of Personality

Attributing the Causes of Behaviour 19

Summary

2 Developing People 29

Stability or Change? $\quad 29$

Incremental Change: Erikson $\quad 30$

Age and Change? 32

Levinson's Theory of Adult Development $\quad 34$

The Search for Personal Meaning $\quad 40$

Applications of the Personality Change Models to Behaviour in Organizations $\quad 44$

Change and Transition 48

Organizational Constraints and Adult Development 53

Summary $\quad 56$

3 Controlling People $\quad 58$

Introduction $\quad 58$

Understanding What Motivates People $\quad 58$

How to Motivate Others 64

Fairness and Justice $\quad 70$

Expectancy, Instrumentality and Valence: An Umbrella Theory 
A Motivating Managerial Style $\quad 77$

$\begin{array}{ll}\text { Summary } & 79\end{array}$

4 Working with Groups $\quad 82$

Definition and Purpose of Groups $\quad 82$

Types of Group $\quad 82$

Group Functions $\quad 83$

Group Dynamics $\quad 85$

Coping with Polarization Effects 101

Summary 105

5 Team Building 107

The Importance of Team Building 107

Group and Team Development 113

Designing Management Teams 115

Other Team-building Approaches 123

Summary 126

6 Leadership 128

Introduction 128

Leadership as Quality or Process? 130

Leadership Style $\quad 134$

Contingency Approaches $\quad 142$

Leadership Reconsidered $\quad 152$

Leadership Skills 153

Summary 155

7 What are Organizations? 158

Definitions 158

Organizational Structures $\quad 162$

The Nature of Bureaucracy 164

The Open-systems Approach 173

Socio-technical Systems $\quad 175$

Work Organization and the Role of the Psychologist 176

$\begin{array}{ll}\text { Contingency Theory } & 179\end{array}$

Summary 180

8 Developing Organizations 185

Successfully Developing Companies 185

Tackling the Problems of Change 188 
Organization Development 194

Summary 208

9 Controlling and Managing Organizations 211 Introduction 211

$\begin{array}{ll}\text { Scientific Management } & 212\end{array}$

Participation 214

The Technological Imperative Versus the End-user Approaches $\quad 217$

Quality Control Circles 221

Total Quality Management 225

Control of Performance - Another Look 227

Concluding Remarks 230

Summary 231

Bibliography $\quad 234$

Name Index 249

Subject Index 253 


\section{Tables}

2.1 Summary comparison of the transformations of personality during various phases of the life span

3.1 A comparison of the basic need theories proposed by Maslow, Alderfer, McClelland and Herzberg

3.2. The assumptions underpinning Theory $\mathrm{X}$ and Theory $\mathrm{Y}$

4.1 The characteristics of mechanistic and organic systems

4.2 An evaluation of six different decision-making techniques 104

5.1 Contrasting behaviours in effective and ineffective groups 108

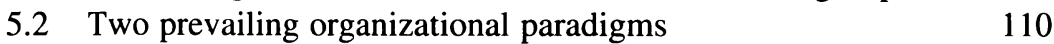

5.3 The characteristics of Belbin's eight team roles 122

6.1 Fiedler's contingency model of leadership effectiveness $\quad 145$

7.1 Characteristics of organizational goals at different hierarchical levels

7.2 'Pure' types of involvement, commitment and power in organizations

7.3 A comparison between three major structural arrangements in organizations

8.1 General characteristics of high and low-innovating companies

8.2 Eight sources of organizational change problems 189

8.3 Management issues and means of resolution

9.1 Technology- versus end-user-centred approaches to organizational work design 


\section{Figures}

1.1 Sources of stress $\quad 11$

$\begin{array}{lll}1.2 & \text { The person-situation-act model } & 14\end{array}$

2.1 Erikson's eight stages of personality development 31

2.2 Levinson's model of the life course 36

2.3 The six interacting systems of personality and their integration $\quad 42$

2.4 Self-esteem changes during transitions 49

2.5 The transition cycle 51

3.1 The Porter-Lawler model of the process of motivation 75

$\begin{array}{lll}6.1 & \text { The managerial grid } & 139\end{array}$

7.1 A schematic diagram of a partial organization chart 163

8.1 The OD cube: a typology of intervention 200

8.2 A cyclical model of interpersonal conflict 205 


\section{Preface to the Second Edition}

The rationale of the original text still stands. Despite the movement in higher education to mass education, mass audiences and the implications for teaching methodology, I believe, perhaps even more fervently, in the need for a 'middle way' which avoids the superficial treatment of the subject. This book is intended to provide such a 'middle way'. It avoids the textbook approach - breadth of coverage but wanting in depth - and is selective, treating particular topics in a detailed manner. It is recognized that students on management courses cannot be expected to read all the original texts and papers upon which particular theoretical developments are based. Indeed, it is questionable whether it is appropriate that they should do so. After all, the managerial contexts in which past research has been carried out have changed and, while there are some seminal works which should be read, we must consider the longer-term applicability of some theories and the accompanying research findings. The study of leadership is a very good case in point. As a history of ideas in management and organizational behaviour/psychology, it makes a fascinating study. But few theories in leadership have stood the test of time. Even some of the most well known, for example Fiedler's contingency theory, have been subjected to heavy criticism.

The danger of not reading past theoretical contributions to the subject is, I can hear someone saying, the tendency to 'reinvent the wheel'. This is another reason why books like The Psychology of Behaviour in Organizations (and there are many examples covering complementary aspects of organizational behaviour) are important. They give students a sense of the richness of the subject - both its systematic and imaginative treatment.

This book should appeal to a wide and diverse audience. It is, of course, primarily directed at students of organizational behaviour but will be of interest to students of applied social psychology and of organizational psychology. It will also be of interest to postgraduate students pursuing an MBA degree and, not inappropriately, post-experience students taking short courses in various aspects of executive management. In this and other ways it is hoped that the book will reach a wider audience of practising managers, for it is only through interaction and dialogue with the practitioner that a subject such as this can produce ideas which are relevant and which lend themselves to the development of better management practice. 


\section{PLAN OF THE BOOK}

The book covers subjects which represent three levels of analysis of behaviour in organizations. As organizations are staffed with people, it is at this level of analysis that the book begins.

Chapter 1 examines the nature of personality and shows how important it is to think of personality not as something which is wholly determined from within but which is affected by the context within which the person operates. The theoretical basis of this account - interactionism - is outlined and examples of applications at the place of work - for example, psychological climate and stress - are described. The approach to understanding personality is reconsidered through an examination of Hampson's social construction theory. Another theoretical approach is that of attribution theory. This process considers the way individuals attribute causes to events; it is important when we consider what might count as evidence for a particular attribution. The implications of these analyses for understanding behaviour in organizations are clearly spelt out.

Chapter 2 tackles the issues of personality development. The issue is one of whether personality changes throughout the life course, or whether perceived differences are merely superficial responses to new situations which leave the basic personality unchanged. Different approaches to dealing with this matter are outlined and their implications for management discussed. Additional material considers how transitional events impact upon the individual, his/her psychological well-being and coping strategies.

Chapter 3 presents the real challenge to management in terms of their understanding what motivates, and how to motivate, subordinates. The coverage of this chapter incorporates need, reinforcement, equity and expectancy theories. A discussion of management style as a motivator is also included.

Organizational life is rarely about individuals acting independently; often tasks are too complex for one person to tackle and accomplish singlehandedly. Efforts need to be coordinated and goals integrated. Thus the second level of the discussion directs attention to the role and function of groups and teams within organizations.

Chapter 4 outlines the nature and function of groups, and in particular examines the effect of normative structure and conformity on decisionmaking behaviour. 
Chapter 5 suggests that of fundamental importance to the organization are its management teams, work groups and specialist groups. The question pursued is how to make such groups operate effectively - indeed, how might one build an effective team in the first place? Several approaches to answering these questions are covered in detail.

Chapter 6 concerns leadership theory. In 1986, when I wrote the first edition of The Psychology of Behaviour in Organizations, leadership research appeared to be in the doldrums. Since that time there has been much rethinking of the role that personality plays in explaining leadership behaviour. This has been demonstrated in the revived interest in the charismatic personality, and in 'transactional and transformational' models of leadership. The chapter concludes with a conceptual model of the skill of leadership.

The third area of discussion focuses upon the organization as such.

Chapter 7 examines what organizations are and the effect of organizational structure on behaviour. The Weberian model of the bureaucratic organization is described in some detail with a critique based on Clegg's analysis. There is a discussion of power and commitment in organizations, and, in addition, socio-technical and contingency models of organizations are described. A critical examination of the role of the organizational psychologist as interventionist is also included.

Organizational environments continue to be characterized as turbulent, imposing a need for responsiveness, flexibility and, in short, change. Chapter 8 therefore looks at pressure for change. In particular the question of the continued relevance of organizational development is examined. The techniques and approach of organizational development are outlined and a plan for the evaluation of change programmes put forward.

Chapter 9 discusses the issue of controlling and managing organizations. It covers scientific management and Taylorism, worker participation in management, quality control circles and total quality management. The issue is the extent to which employees have a say in how they are managed, and the psychological and structural factors which affect the balance between worker and managerial control.

Finally, I would like to add that I am delighted that this book has gone into a second edition. I hope that the book will continue to be of use to students and teachers of organizational behaviour in the years to come. 


\section{Acknowledgements}

Producing the revisions has been quite a protracted process and I should acknowledge most sincerely my debt of gratitude to Belinda Holdsworth and her predecessor Frances Arnold at the publishers for the encouragement they have given me and for the patience they have displayed. Carrying out these revisions has coincided with the process of leaving one institution and taking up a quite challenging post in another. This has made life extremely interesting and it has made the preparation of the manuscript even more protracted!

It is 'normal' in a personal statement of acknowledgement such as this to thank one's family and friends for their support. In my own case I have to say that since the first edition of this book, my family has dwindled and I have lost some five members of it, those particularly close to me being my father and my grandmother. This has meant that I have been called upon to be supportive and to draw upon my own inner reserves. While this has, on occasions, been a strain, I have throughout enjoyed the support of a few dear friends - friends whom I have come to appreciate more and more.

E. C.

The author and publishers gratefully acknowledge permission from the following to reproduce copyright material:

Figure 1.1, 'Sources of Stress' from J. Marshall and C. L. Cooper, Executives under Pressure, (C) 1979 Judi Marshall.

Figure 1.2, 'The Person-Situation-Act model' from International Small Business Journal, 3, 3, p. 50, (C) 1985, Woodcock Publications.

Figure 2.1, 'Erikson's Eight Stages of Personality Development' from E. H. Erikson, Childhood and Society 2nd edn, (C) 1963 Norton.

Figure 2.2, 'Levinson's Model of the Life Course' from N. Smelser and E. H. Erikson (eds), Themes of Work and Love in Adulthood, p. 283, (C) 1980, Harvard University Press. 
Figure 2.3, 'The Six Interacting Systems of Personality and their Integration' from A. Powell and J. R. Royce, 'Paths to Being, Life Style and Individuality', in Psychological Reports, 42 (1978) (C) Joseph Royce.

Figure 2.4, 'Self-esteem Changes during Transitions' from J. D. Adams, J. Hayes and B. Hopson, Transition: Understanding and Managing Personal Change, p. 13, (C) 1976 John Adams, John Hayes and Barrie Hopson.

Figure 2.5, 'The Transition Cycle' after N. Nicholson, 'The Transition Cycle: Causes, Outcomes, Processes and Forms', from S. Fisher and C. L. Cooper (eds), On the Move: The Psychology of Change and Transition, p. 87, (C) 1990 The Society for the Psychological Study of Social Issues, reprinted by permission of John Wiley \& Sons Ltd.

Figure 3.1, 'The Porter-Lawler Model of the Process of Motivation' adapted from L. W. Porter and E. E. Lawler III, Managerial Attitudes and Performance, (C) 1968, Irwin-Dorsey.

Figure 6.1, 'The Managerial Grid' from R. R. Blake and J. S. Mouton, The Managerial Grid: Key Orientations for Achieving Production through People, (c) 1964, Gulf.

Figure 8.1, 'The OD Cube: A Typology of Intervention' adapted from an idea devised by R. A. Schmuck and M. B. Miles, Organization Development in Schools, 1971, University Associates.

Figure 8.2, 'A Cyclical Model of Interpersonal Conflict' from p. 72 of R. E. Walton, Interpersonal Peacemaking, (C) 1969, Addison-Wesley.

Table 2.1, 'Summary Comparison of the Transformations of Personality during Various Phases of the Life Span' from J. R. Royce and A. Powell, Theory of Personality and Individual Differences: Factors, Systems and Processes, p. 250, (C) 1983, Prentice-Hall, Inc., Englewood Cliffs, New Jersey.

Table 3.1, 'A Comparison of the Basic Need Theories proposed by Maslow, Alderfer, McClelland and Herzberg' from E. H. Schein, Organizational Psychology, 3rd edn, p. 30, (c) 1980, Prentice-Hall.

Table 4.2, 'An Evaluation of Six Different Decision-making Techniques' adapted from K. Murnighan, 'Group Decision-making: What Strategies 
Should You Use?', Management Review, February 1981, p. 61, (C) 1981 American Management Association, New York.

Table 5.2, 'Two Prevailing Organizational Paradigms' from R. Thomsett, People and Project Management, p. 37, (C) 1980. Reprinted by permission of Prentice-Hall Inc., Englewood Cliffs, New Jersey.

Table 5.3, 'The Characteristics of Belbin's Eight Team Roles' from R. M. Belbin, Management Teams, p. 78, (C) 1981, Heinemann Educational Books.

Table 6.1, 'Fiedler's Contingency Model of Leadership Effectiveness', adapted from F. Fiedler, A Theory of Leadership Effectiveness, p. 37, (C) 1967, Fred E. Fiedler.

Table 7.3, 'A Comparison between Three Major Structural Arrangements in Organizations', adapted from F. Blackler and S. Shimmin, Applying Psychology in Organizations, (c) 1984, Methuen.

Table 8.1, 'General Characteristics of High- and Low-Innovating Companies', from R. M. Kanter, The Change Masters, (C) 1984, Unwin.

Table 8.2, 'Eight Sources of Organizational Change Problems', from M. Woodcock and D. Francis, Organizational Development through Teambuilding, pp. 6-7, () Gower.

Table 9.1, 'Technology- versus End-User-Centred Approaches to Organization Work Design', adapted from F. Blackler, 'Information Technology and Competitiveness: Signposts from Organizational Psychology', paper presented to the Occupational Section of the British Psychological Society Conference, Nottingham, January 1986.

Material abstracted and adapted from D. M. McGregor, The Human Side of Enterprise, (C) 1960, McGraw-Hill (tables 3.2 and 5.1).

Material abstracted and adapted from T. Burns and G. M. Stalker, The Management of Innovation, (C) 1961, Tavistock Publications (table 4.1). 